\title{
顔面骨骨折の統計的観察
}

\author{
丸山裕美子 · 三輪 高喜 $\cdot$ 作本 真 \\ 長山 郁生・古川 仞

\section{Clinical Statistics on Facial Bone Fracture} \\ Yumiko Maruyama, Takaki Miwa, Makoto Sakumoto, \\ Ikuo Nagayama and Mitsuru Furukawa \\ (Kanazawa University)
}

\begin{abstract}
At our clinic, we encountered 272 cases of facial bone fracture between 1983 and 1993 . These patients were analyzed by age, gender, cause and location of the fracture.

There were 202 nasal bone fractures, which comprised 59.3\% of all facial bone fractures. Males were significantly predominant $(75.2 \%)$. These injuries mainly occurred during sports, fighting and automobile accidents.

While usually single and rather slight bone fractures such as nasal bone fractures occured during sports, more severe fractures involving many facial bones occured in high speed, such as automobile accidents. Moreover, orbital bone fractures mainly resulted from fightings or sports. Precise otolaryngological knowledge and management is indispensable for ENT clinicians.
\end{abstract}

Key words : facial bone fracture, nasal bone fracture, sports, fighting

はじめに

顔面外傷は日常よく遭遇する疾患であるが，顔面とい う特殊部位であるため形態的にも機能的にもその治療が 重要な疾患である.

近年，スポーツ，交通事故，労働災害などを中心とす る様々な原因により顔面骨骨折をはじめとする顔面外傷 は多様化してきている。このため，これらの外傷に対す る治療は質，量ともに高度なものが要求されるよらにな ってきているまたとの部位的な特殊性からもわずかな 変形でも患者にとっては重大な後遺症として意識される ことが多い。したがって，顔面を日常診療の対象とする 耳鼻咽喉科としては，顔面外傷の処置に習熟し，充分な 知識をるつ必要がある。

今回われわれは1983年 1 月から1993年 5 月までの過去 11年間に打いて，金沢大学附属病院耳鼻咽喉科を受診し た272例の顔面骨骨折症例について統計的観察を行い,
骨折部位, 受傷原因, 年龄分布, 性別につき個々の因子 の相互関係を分析し，興味深い結果を得たので若干の考 察を加え報告する。

\section{統計的観察}

\section{1. 骨折部位内訳}

顔面骨骨折の骨折部位別にその割合を示す（図 1)。な 陉骨折した部位に注目するために, 複合骨折は各々の複 数の部位での骨折としてとらえた. このため, のべ症例 総数は341例だった。また眼窩底骨折，眼窩内側壁骨折 を含む眼窩壁の骨折は全て眼窩骨折として集計した，鼻 骨骨折が最も多く(202例) $59.3 \%$ であり，以下上顎骨骨 折, 眼窩骨折, 煩骨弓部骨折を含めた煩骨骨折, 下顎骨 骨折，前頭骨骨折の順であった．耳鼻咽喉科を受診する 顔面骨骨折は鼻骨骨折が最多であり，また上顎成分の骨 折が全体の $97.1 \%$ 占めていた。 


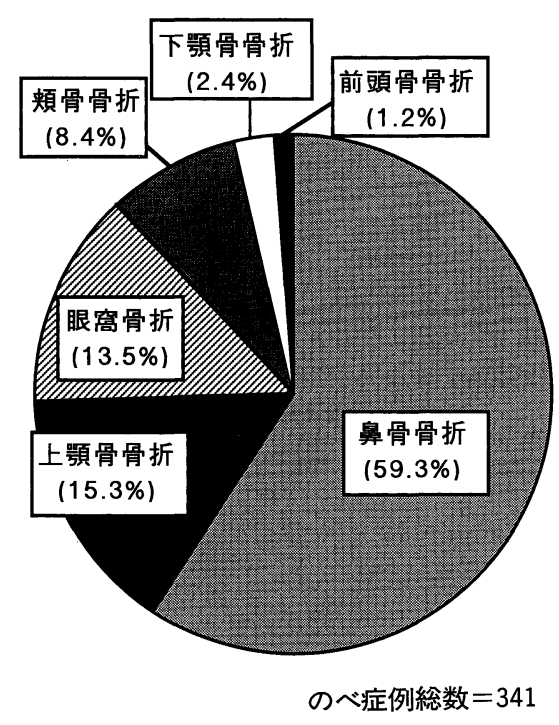

図 1 顔面骨骨折分別

上顎骨骨折は Le Fort の分類がよく知られているが典 型的なものは少なく, 種々のタイプの組み合わさったも のや，不完全型が多かった。

2 . 年度別受傷患者数の变化・男女比

次に年度別に受傷した骨折患者数の変移を調べてみた （図 2)．経時的に明らかな増加減少の傾向は見られず， 年間の受診者の平均は 24.8 人であった。 また，いずれの 年に打いて子男性の受診者は女性のそれを上回って扮り， 全体でみると男性が $75.2 \%$ ，女性が $24.8 \%$ で $3 / 4$ を男性 が占めていた。

\section{3 . 年齢別構成}

年齢別構成について図 3 亿示す．受傷年齢は 1 歳から 80歳までと幅広い分布を示していたが，10代にピークが 存在し，しかも10代20代に65.8\%が集中していた．40歳 以下では男性の受診者数は女性のそれを明らかに上回っ て括り, 特に 10 歳代, 20 歳代では男性は女性の 3 倍以上 であることがわかった。

4. 月別の受傷件数

受傷した月毎の人数比較および，その受傷原因の内訳 を調べてみる(図4）。

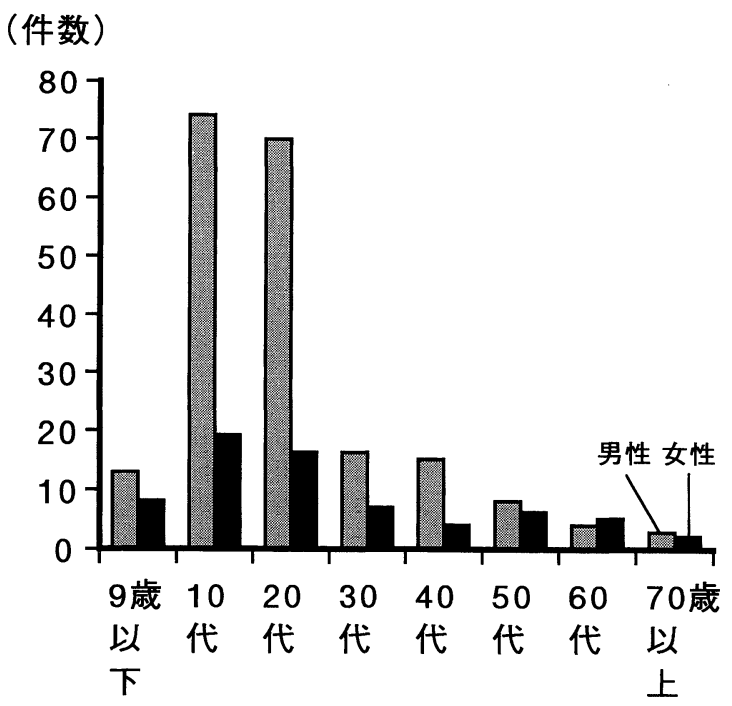

図 3 年齢別男女比

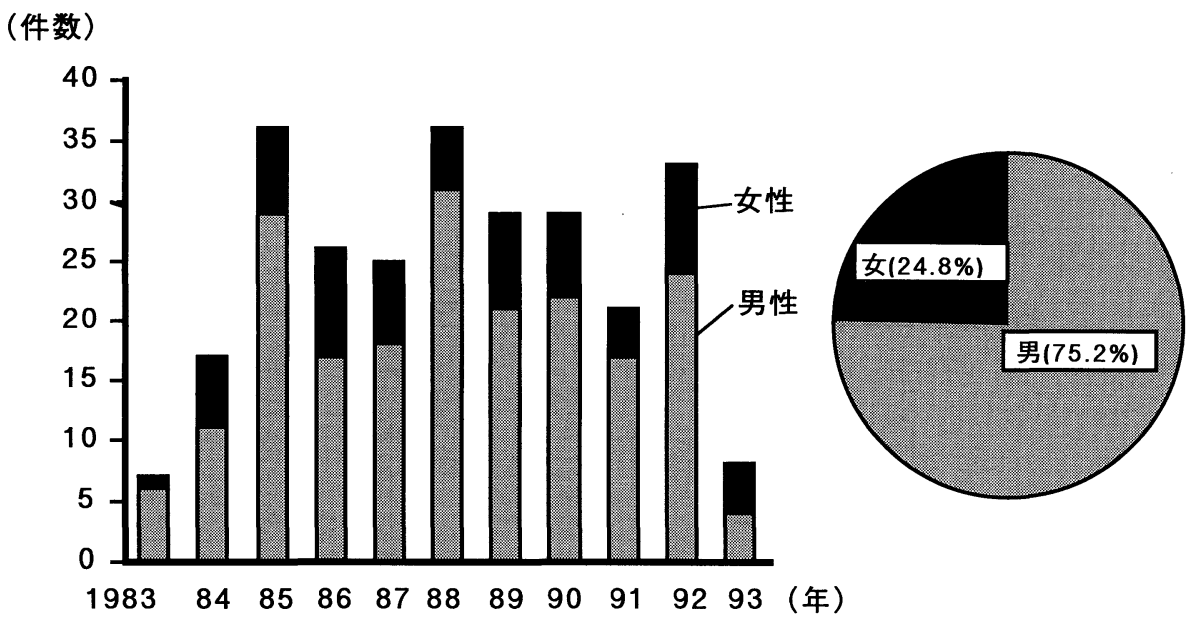

図 2 年度別受診者数 


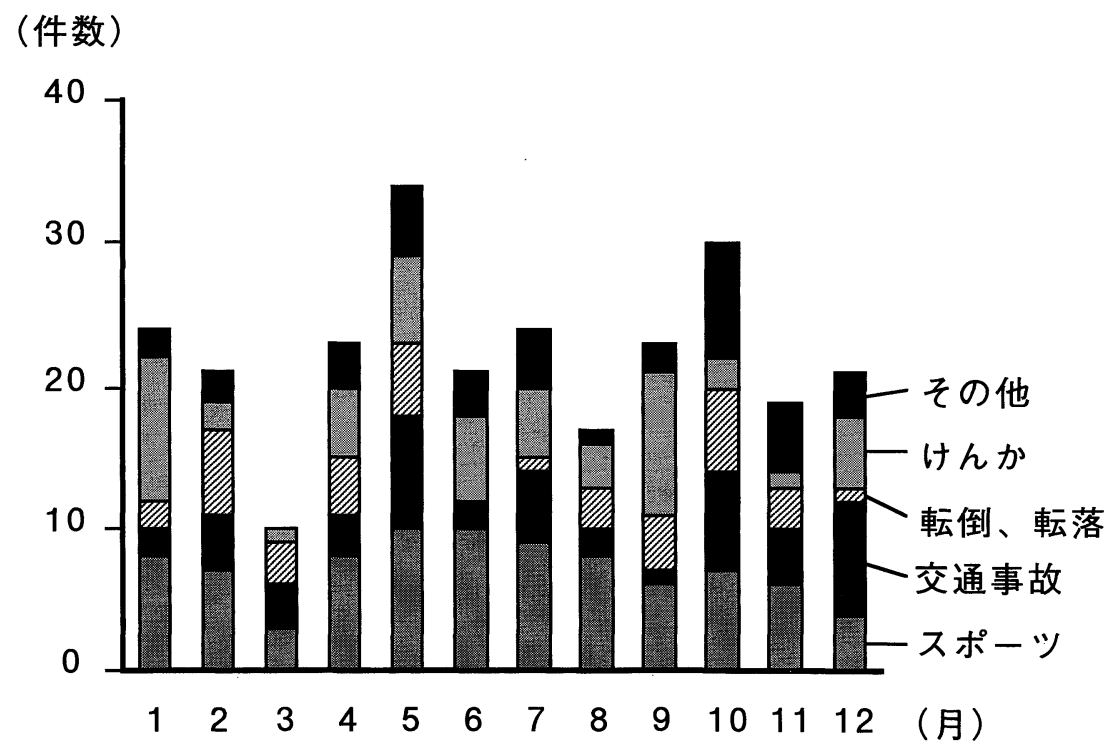

図 4 受傷月別の件数

まず全体として，受傷件数は 5 月，10月に多く，3月， 8 月に少なかった. 興味深いのは交通事故によるものが 12 月， 5 月に多いこと，またけんかは 1 月， 9 月に多い ことなどである。

\section{5. 受傷原因}

さらに受傷原因に関し，統計的検討を加えてみる(図 $5)$.

全体ではスポーツによる受傷が最も多く31.6\%(86例) であり，以下けんか，交通事故，転倒・転落の順であっ た.スポーツの内容としては野球・ソフトボール, ラグ
ビー, バスケットボール等の球技による受傷が多数みら れた．また男女別に原因の検索を行ったところ，男性に スポーツ，けんかの割合が多かった(図 6 ).

\section{6. 受傷原因と骨折部位}

受傷原因と骨折部位の関係を調べたところ, 図 7 亿示 すようにスポーツ，けんかに执いては鼻骨骨折が比較的 高い割合を示すのに対し，交通事故，転倒転落では上領 骨骨折执よび煩骨骨折の占める割合が増加していた。さ らにけんかで眼窩骨折が多いのはいわゆる blowout fracture の発生機序と関係があるものと考兄られる.

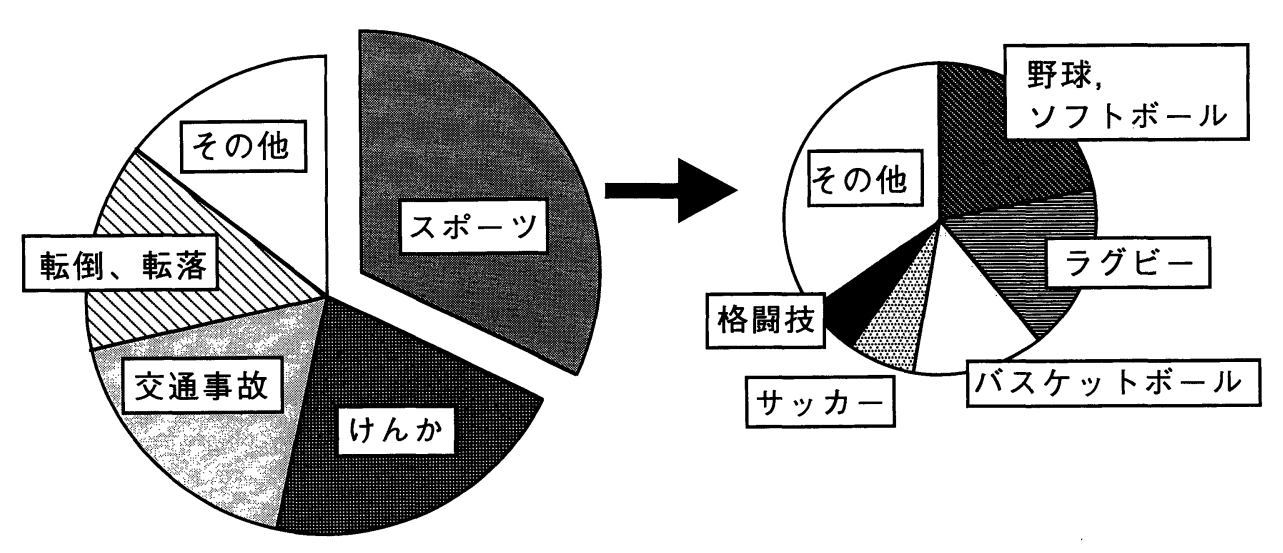

図 5 受傷原因(全体) 

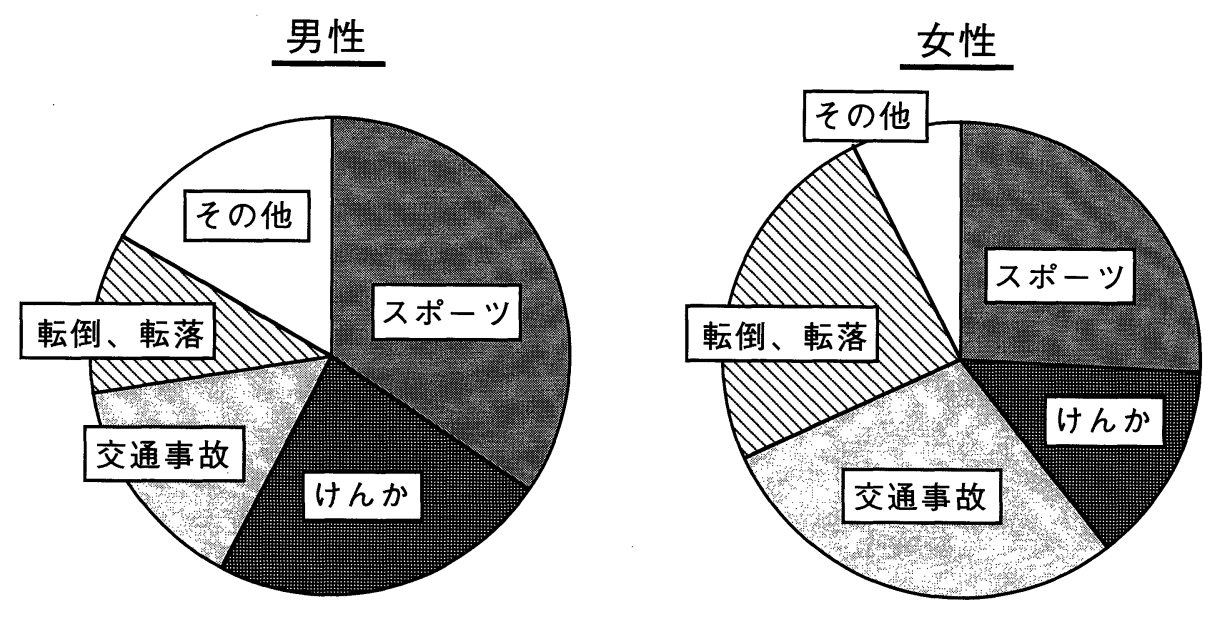

図 6 受傷原因(男女別)

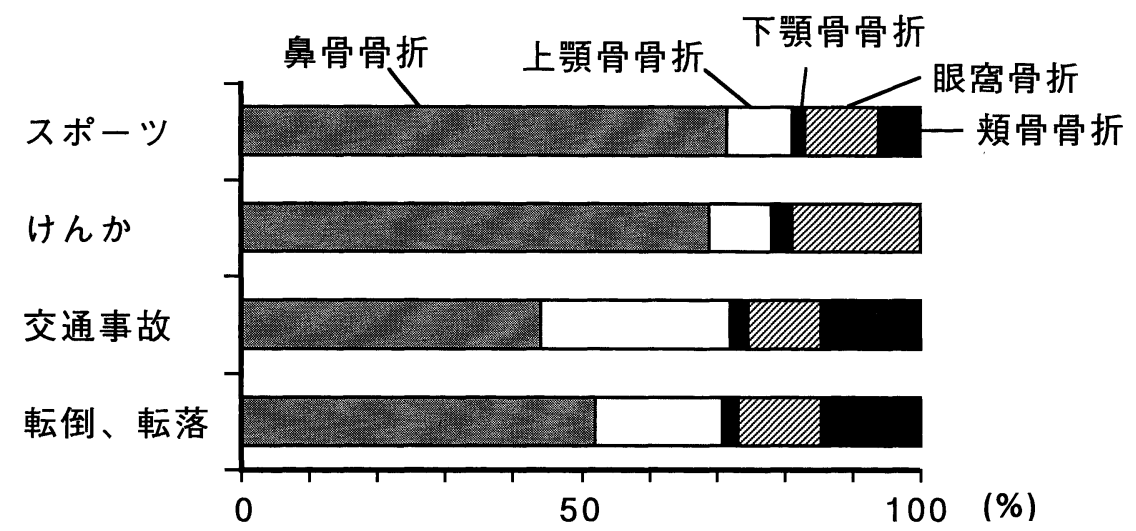

図 7 原因と骨折部位

\section{7. 原因別年齢構成}

各々の原因別にその年齢分布を調べてみた（図８）。 ス ポーツおよびけんかは10歳代, 20歳代の若者の割合が明 らかに高いことがわかる。一方で交通事故, 転倒転落は 各年代に見られるが，転倒転落は 9 歳以下の子供が $1 / 4$ 以上を占め，また交通事故ではな衫10代，20代が多いの は各年代層の行動様式を反映する結果と考兄られる.

\section{8. 治療方針}

当科受診患者の治療方針をグラフに示寸(図 9). 外来 にて整復治療したのはすべて鼻骨骨折の症例で，いずれ も非観血的整復固定術を施行している.入院治療の割合 が最も多いのは骨折が 2 種以上の部位に及ぶ複合骨折で あり，逆に外来での経過観察の割合が最も多いのは眼窩
単独骨折のものであった．これらは患者の訴兄と症状， 病態等をもとにした総合的判断の結果を反映していると 考光られる.

9. 受傷後手術までの日数

入院治療を行った症例に対し受傷から手術までの期間 について鼻骨単独骨折とそれ以外の顔面骨骨折とに分け て比較検討を行った(図10)。鼻骨骨折では受傷から手術 までの日数のピークは 5 日，平均 10.03 日であるのに対 し，その他の顔面骨骨折ではピークは11日，平均 12.54 日だった。しかしいずれの平均日数も受傷後 2 週間以内 に手術を施行している.

以上の結果は鼻骨単独骨折にくらべ，それ以外の顔面 骨骨折では複雑な症状を伴うことも多く, 全身状態, 骨 


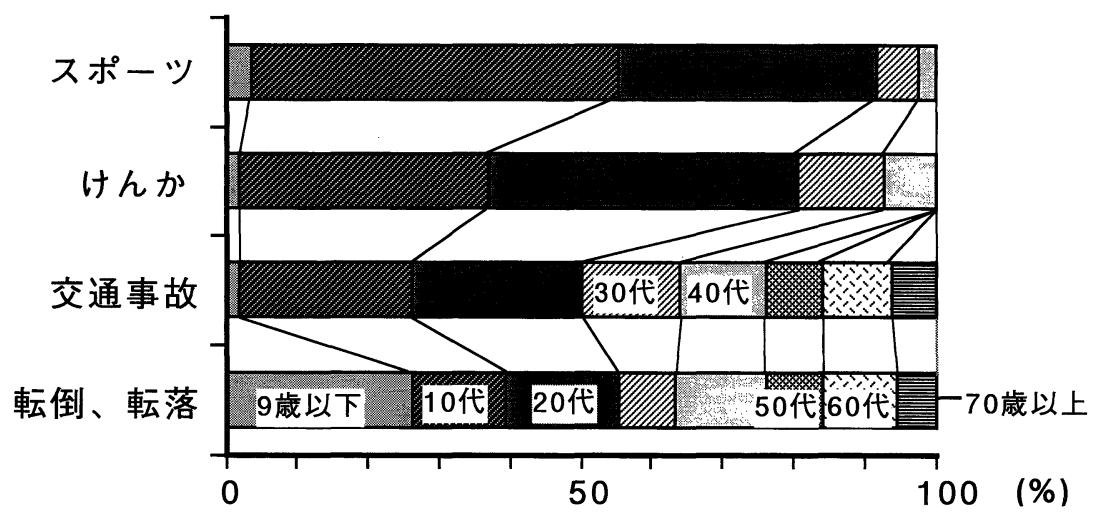

図 8 原因と年齢

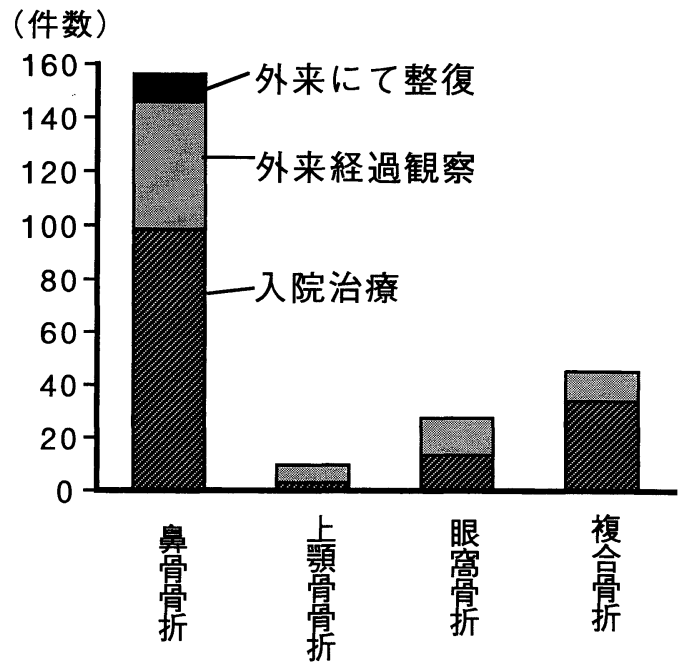

図 9 治療方針

折部位の把握, また術前の病態の管理等に要する時間が 長く必要であることを示すものと考えられる.

\section{0. 治療内容}

治療内容について，表に示す(表 1 ).

鼻骨骨折では非観血的整復がその大部分を占めた。上 顎骨骨折に対しては口のら部切開による上顎骨前壁また は上顎洞からアプローチした症例が多くあった。

眼窩骨骨折に関しては同じくロのう部切開による上顎 洞内アプローチがその主な治療法だった. 下眼瞼切開に よるアプローチ例や篩骨洞へ上顎洞よりアプローチを加 えた例もあった．眼窩壁の補強のため，シリコンプレー トや自家骨片の移植を行った症例も見られた. 固定法は 上顎洞内にガーゼタンポンを行った例が主であったが，
バルーン固定をした例もあった。

これに対して頓骨骨折については，骨折部位，転位の 度合, 症状, 可動性等の状態も多種多様で, それに対す る術式もさまざまだった。概して骨折した頓骨の固定は 容易ではなかった。

\section{考察}

以上過去 10 年間で当科を受診した顔面骨骨折患者 272 例に対し，多角的に比較検討した。

全体的な骨折部位別症例数については例えば鼻骨骨折 に関し Schultzi) は32\%藤野2) は28.7\%田嶋ら3)は21\%， 古川ら4) が49\%との報告があるのに対し，当科では 59.3 \%と高い値を示している。これは今回の集計が耳鼻咽喉 科で行われたものであることが大きく関与していると考 えられる。

調所ら ${ }^{5)}$ は耳鼻咽喉科では顔面骨の中 $1 / 3$ すなわち上 顔面の損傷者の受診が多く，これに対し，歯科口腔外科 では顔面下 $1 / 3$ と中 $1 / 3$ が多く, 形成外科は顔面中 $1 / 3$ と軟部組織の損傷者の受診が多いことを示している.こ れは諸家の報告に一致する6).

年齢別発生頻度では諸家7) 12) の報告を見ても10代か ら30代の若者に多く，男女比については，諸家いずれの 報告でも男性が女性より $3 \sim 5$ 倍多いとされて扣り, 著 者らの調査もこれに一致した。

Schultz ${ }^{1)}$ の報告 (1967) では，受傷原因は交通事故， 家庭内事故，スポーツの順に多く，藤野2）の報告 (1977) では交通事故，スポーツ，けんかの順に多く，そして調 所ら5)の報告(1984) ではスポーツ，けんか，交通事故の 順に多いとされている。立木ら 6 (6) の報告(1984)でも，ス 

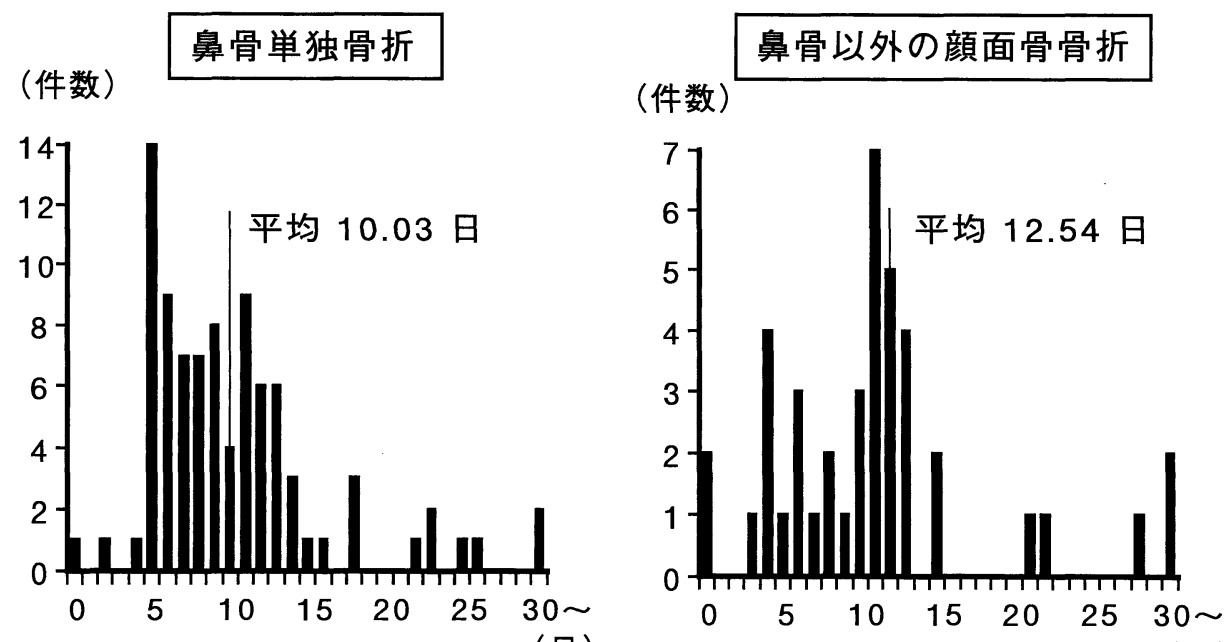

(日)

(日)

図10 受傷から手術まで

表 1 治療内容

\begin{tabular}{|c|c|c|c|}
\hline 骨折部位 & & 治療法 & 症例数 \\
\hline \multirow{2}{*}{ 鼻骨骨折 } & 外来 & $\begin{array}{l}\text { 経過観察 } \\
\text { 外来にて整復 }\end{array}$ & $\begin{array}{l}51 \\
10 \\
\end{array}$ \\
\hline & 入院 & $\begin{array}{l}\text { 観血的鼻骨骨折整復術 } \\
\text { 非観血的鼻骨骨折整復術 }\end{array}$ & $\begin{array}{r}6 \\
101\end{array}$ \\
\hline \multirow[b]{2}{*}{ 上顎骨骨折 } & 外来 & 経過観察 & 13 \\
\hline & 入院 & 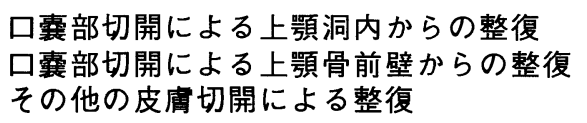 & $\begin{array}{r}12 \\
17 \\
1\end{array}$ \\
\hline \multirow[b]{2}{*}{ 眼窩骨折 } & 外来 & 経過観察 & 18 \\
\hline & 入院 & 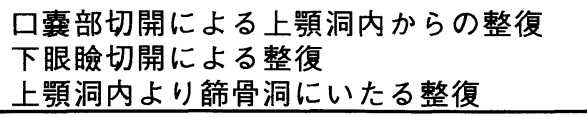 & $\begin{array}{r}16 \\
1 \\
4 \\
\end{array}$ \\
\hline \multirow[b]{2}{*}{$\begin{array}{l}\text { 规骨骨折 } \\
\text { (体部, 弓部 } \\
\text { を含む) }\end{array}$} & 外来 & 経過観察 & 5 \\
\hline & 入院 & $\begin{array}{l}\text { 口襄部切開による上顎骨前壁からの整復 } \\
\text { Gillies temporal approach } \\
\text { 眉毛外側切開 } \\
\text { 下眼瞼切開 } \\
\text { その他の皮庫切開 }\end{array}$ & $\begin{array}{l}3 \\
3 \\
6 \\
5 \\
6\end{array}$ \\
\hline
\end{tabular}

ポーツ，交通事故，けんかの順に多い. Muraoka ら ${ }^{13)}$ の報告(1991)では，交通事故，けんか，転落の順であっ た。著者らの集計では，スポーツ，けんか，交通事故の 順に多いといら結果であった。

受傷原因は国別および時代や地域の情勢を反映し変化
するものである. 現代の日本に拈いては，多様化するス ポーツとスポーツ人口の増加, 自動車社会化, 等を考㝋 合わせれば，更にスポーツ外傷，交通事故による骨折は 多くなるものと考觉られる.

今回，骨折の原因とその発生部位についての統計的検 
索を加えた結果, 一般に考兄られているごとく，スピー ドが遅く, 硬度の低い外力により比較的軽度の単独骨折 が生じ，逆にスピードが速く，硬度が高い外力によって 複雑な複合骨折が発生することが裏付けられた。また， blowout fracture の原因として統計的にもけんかが多か ったことは諸家の研究を支持する結果となった ${ }^{14)}$.

さらに受傷原因と, 年齢分布との関係を調查したとこ ろ, これは各年代別での行動の特徵との関連性の認めら れる興味深い結果を示した。つまりスポーッ，けんかに よる受傷は 10 代， 20 代が全体の 8 割以上を占め， 50 歳以 上の高齢者症例はなく, 転倒, 転落は全年齢にまんべん なく起こるが，9歳以下の小児に多発していた。一方で 交通事故による受傷も全年齢に起こりらるがやはり 10 代， 20代がその半分以上を占めていた.

今回の集計の全体を通じて感じられたことはやはり， 青年男性一スポーツ拈よびけんか一鼻骨骨折といらパ ターンが目立って多いといらことであり ${ }^{8199 ， こ れ は 耳 ~}$ 鼻咽喉科といら特殊性に関連があると考它られる。

治療に関しての詳細は, 成書に譲る15) が, 当科の治 療方針としては，鼻骨骨折では新鮮骨折のらちであれば 徒手整復で整復可能であり, 陳旧例や他の部位に重複骨 折を見る例では観血的整復を行ったままた，形態的掞よ び機能的異常の度合いや，患者の年齢，本人の希望を考 慮したらえで経過観察のみとし整復を必要としなかった 例もある。

上顎骨骨折に対してはその観血的治療のほとんどで口 囊部切開を行い眼窩下神経の圧迫除去し，金属プレート や上顎洞内のガーゼタンポンまたはバルーンを用いた固 定整復を行った。頓部知覚障害は, 軟部組織障害や打撲 による一過性のものであることもあり，CT をはじめと するX線画像の読影が大切となる.

眼窩骨折についてはその手術商応に関して，X線上明 らかな骨折所見を認めかつ眼球運動制限と複視の存在す る例には，早期の手術を勧める考学 ${ }^{16)}$ や一定期間以上 続く主要眼症状を有する症例に手術を行らといら考兄 や1718), traction test 重要視する考兄 ${ }^{3)}$ 等が見られる が，近年当科では眼科医の協力のもと Hess test，traction test を行い，その手術適応を決める傾向にある。い わゆる blowout fracture の場合には上䋶骨骨折と同様上 顗洞内からのガーゼタンポン, バルーンによる眼窩底の 固定が行わ机るが，シリコンプレートや自家骨移植を行 った例もある。な招シリコンプレート挿入の際は後遺症
としての感染に特に注意すべきである．眼窩骨折が顔面 骨骨折の中で保存的療法の割合が最も高いのも (47.3\%) 眼窩骨折の治療方針の特徵の 1 つと言兄る.

頓骨弓部执よび頓骨体部骨折はその治療法が最も多岐 にわたる、これは, 受傷早期より受傷部の腫脹が強く起 こるため骨片の転移による変形が視診, 触診上明らかで ないこと, 異常可動性が明確でないこと, tripod fracture の様な典型例もさることながらその骨折部位や変 形の度合いが様々であること，重複骨折を見る例が多か ったことがその理由としてあげられる. 早期の完全整復 そのものがある程度固定力をもつ. しかし，上述のごと く早期診断が難しくまた顔面であるだけに外科的治療が ためらわれることもあり，観血的整復をする時期にはそ の整復・固定はさらに難しくなる傾向にある. 今後は 3 次元 CT 等も用いた正確な早期診断早期治療が望まれる. 主な整復法としては Gilles temporal approach, 眉毛外 側切開による整復, 骨折部直上皮膚切開による整復, 下 眼瞼切開による整復があげられ，また，固定法としても 金属プレート，キルシュナー鋼線を用いた固定，上顎洞 内からの固定等と, やはりその症例に最適な方法を多数 の選択肢の中から選ぶことになる.

骨折全般にいえることであるが，受傷後早期の整復ほ ぞ機能的形態的に完全修復に近い、治療が可能であるのは 周知の事実である. 診断に際しては, 問診, 視診, 触診 はもちろんのこと, やはり CT を含む各種X線の読影に 習熟すべきである。また，陳旧例に対しては骨の吸収や 増殖, 軟部組織の拘縮に留意する必要がある. また, 正 確かつ完全な整復はそれ自身ある程度の固定力を有し， 逆に不十分な授動整復は強固な固定によっても再転位を きたす恐れがある.このため, 整復は完全な解剖学的位 置関係の再現に努めることが大切で, 固定は整復位を static 飞保持するための手段ととらえるべきと考光られ る.

顔面骨骨折は鼻副鼻腔機能や咀嚼機能さらには, 頭蓋 底や眼窝を含む広範な形態と機能の異常をきたしらる疾 患であり，その管理と矯正に関しては複数科での知識と 技術を集結させた包括的な治療が必要な場合も多いと考 えられる.このためにも各科同士の充分な連絡, 理解拉 よび協力が大切であり, 特に上顎成分での障害について は，耳鼻咽喉科医は適確な見地をもって主導的立場をと るべきであり，さらに治療経験を積み，機能損傷に対す る専門的知識を修得する必要があると考兄られる。 


\section{まとめ}

1983年 1 月より1993年 5 月までの 11 年間に当科で取り 扱った顔面骨骨折272例について年齢，性別，骨折部位， 原因等につき，それらの間の相関をも含めて検討を加え た。

\section{参考文献}

1) Schultz RC : Facial injuries from automobile accidents; a study of 400 consecutive cases. PRS $40: 415 \sim 425,1967$.

2 ) 藤野豊美 : 顔面骨骨折の臨床 外傷の種類と骨折のパター ンについて. 災害 $20: 339 \sim 345,1977$.

3 ) 田嶋定夫, 中島龍夫, 丸山 優, 他 : 眼窩内骨折 (blowout fractures) に扣ける諸症状, 手術成績に関する考察. 形成 外科 $20: 184 \sim 190,1977$.

4) 古川雅祥, 最所裕司, 浜中孝臣, 他: 当院に打梳る顔面骨 骨折 5 年間の統計. 形成外科 $25: 213 \sim 218,1982$.

5 ) 調所廣之, 永井大介, 渡辺尚彦, 他 : 鼻骨骨折の臨床. 日 災医誌 32 : 310 312, 1984.

6 ）立木圭吾, 竹中 洋, 後藤達也, 他: 当科に拈ける顔面骨 折症例. 日耳鼻 $92: 37 \sim 45,1989$.

7 ）丸岡健一, 中井義明, 村岡道徳, 他 : 当教室に打ける顔面 骨骨折 5 年間の統計。耳喉 $58: 471 \sim 476,1986$.

8 ）西村秀夫, 小野寿之, 上出一朗, 他 : 耳鼻咽喉科に扣ける 顔面骨折の臨床．耳鼻臨床 $72 ： 1237 \sim 1243,1979$.

9 ）成尾一彦, 鶴田至宏, 田中 治, 他 : 最近 6 年間の鼻骨骨 折の臨床統計. 耳鼻臨床 $85: 565 \sim 574,1992$.
10）高橋 良, 飯田 収：鼻副鼻腔外傷について。耳喉 38 : 1275 1287, 1966.

11）藤谷 哲, 相馬 恵, 杉内智子, 他 : 鼻骨骨折の統計と診 断. 耳展 $30: 471 \sim 476,1987$.

12）加勢 満, 三輪高喜, 宮和貴夫, 他 : 鼻副鼻腔外傷の統計 的観察. 耳展 $29: 177 \sim 180,1986$.

13) Muraoka $M$, Nakai $Y$, Shimada $K$, et al : Ten-year statistics and observation of facial bone fracture. Acta Otolaryngol Suppl (Stockh) $486: 217 \sim 223,1991$.

14) Pfeiffer RL : Traumatic enophthalmos. Arch Ophth 30 : $718 \sim 726,1943$.

15）草間 悟, 和田達雄, 三枝正裕, 他 : 顔面外傷. 外科 Mook $21: 1 \sim 283,1981$.

16) Converse JM, Smith B, Obear MF, et al : Orbital blowout fractures; a ten-year survey. Plast Reconst Surg 39 : 20 36, 1967.

17) Emery JM, von Noorden GK, and Schlernitzauer DA : Management of the orbital floor fractures. Am J Ophthalmol 74 : 299, 1972.

18) Hammerschlag SB, Hughes S, O'Reilly GV, et al : Another look at blowout fractures of the orbit. AJNR $3: 331 \sim 335,1982$.

$$
\left(\begin{array}{l}
\text { 原稿受付 : 平成 } 6 \text { 年 } 10 \text { 月 } 12 \text { 日 } \\
\text { 原稿採択 : 平成 } 6 \text { 年 } 12 \text { 月 } 28 \text { 日 } \\
\text { 別刷請求先 : 丸山裕美子 } \\
\text { † } 920 \text { 金沢市宝町 } 13-1 \\
\text { 金沢大学医学部耳鼻咽喉科学教室 }
\end{array}\right)
$$

